\title{
KRYTYCZNY ZWROT \\ KU SOCJOLOGII OBYWATELSKIEJ ${ }^{1}$
}

\author{
Michael Burawoy
}

Punktem widzenia dawnego materializmu jest społeczeństwo „obywatelskie”; punktem widzenia nowego materializmu jest spoteczeństwo ludzkie, cryli uspołeczniona ludzeosíc.

Filozofowie rozmaicie tylko interpretowali śniat; idzie jednak o to, aby go zmienic ${ }^{2}$.

Karol Marks

Powrót do „radykalnej socjologii” lat 70. nie przynosi nic innego, jak tylko zdumienie nad jej nieokazującym skruchy akademickim charakterem, zarówno w kwestii jej analitycznego stylu, jak i oddalenia od rzeczywistości. Stanowiła ona odbicie świata, który miała zwyciężyć. Przy całym swoim radykalizmie była nastawiona na transformację socjologii, a nie społeczeństwa. Tak jak młodohegliści, o których tak pogardliwie wyrażali się Marks i Engels, frazę zwalczaliśmy frazą, robiąc rewolucję za pomocą słów. Obsesja na punkcie teorii brała się nie z doświadczenia życiowego lub ze zdrowego rozsądku klas niższych, ale ze sprzeczności i anomalii abstrakcyjnych programów badawczych. Publicznością dla naszych reinterpretacji marksizmu i śmiertelnie poważnych diatryb przeciw socjologii burżuazujnej nie były jednak podmioty historycznej zmiany - pracownicy, rolnicy, przedstawiciele mniejszości - ale wąskie grono intelektualistów, w większości odciętych od świata, który chcieli reprezentować. Ważny wyjątek stanowił feminizm, o którym Catherine

\footnotetext{
${ }^{1}$ Podziękowania dla Rhondy Levine, Eddiego Webstera i Erika Wrighta za ich komentarze do wcześniejszego szkicu niniejszego artykułu. Ten artykuł został opublikowany pierwotnie w pracy Levine (2004) i przedrukowany za jej zgoda.

${ }^{2}$ K. Marks, 1975. Tezy o Feuerbachu, w: K. Marks, i F. Engels, Dzieła, t. 3. Warszawa: KiW, s. 5-8.
} 
MacKinnon (1989: 83) pisała, że był „pierwszą teorią, której dane było wyłonić się spośród tych ludzi, których interesów dotyczyła”, ale nawet on, choć wymagal związków z doświadczeniem, nie był wolny od ryzyka przeteoretyzowania.

Z pewnościa część radykalnych socjologów podejmowała działalność polityczną w okopach społeczeństwa obywatelskiego, lecz głównie ze względu na przepaść oddzielająca ją od pracy akademickiej - zaiste, ironiczne wcielenie idei oddzielenia polityki i nauki Maxa Webera. Taka aktywność polityczna mogła bowiem stanowić ukrytą siłę napędowa socjologii krytycznej, lecz rzadko kiedy dostarczała ona tej ostatniej wkładu merytorycznego lub kierunku. Celem tego eseju jest wydobycie owej siły napędowej na światło dzienne, nazwanie jej, udoskonalenie i poszerzenie o nią socjologii obywatelskich (public sociologies). Uważam, że socjologia krytyczna (critical sociology) zajmuje się rozwojem socjologii obywatelskich i powinna to czynić w większym stopniu, choć tylko w odniesieniu do określonego ich typu.

\section{/// Pięćdziesiąt lat socjologii: od ideologii do utopii}

Jeśli przedstawiona tu przeze mnie kolekcja przykładów jest typowa, to zadaniem „socjologii radykalnej” nie było wyprodukowanie konkretnej wizji, mogącej opanować wyobraźnię i pobudzić zapał klasy niższej, lecz przekonanie intelektualistów, w szczególności akademików, do potęgi myśli marksistowskiej. Wywracając powszechne przekonania, chcieliśmy zademonstrować, że marksizm był prawdziwą nauka, podczas gdy socjologia była jedynie ideologią. Gdy zwracaliśmy się do grona naukowców, czasem nawet wierzyliśmy, że w istocie to my jesteśmy tą klasą czy też jej frakcją która ma pisać historię - porównywalną z „klasą specjalistów i kierowników (proffesional-managerial class)" Ehrenreichów (1977) lub wszechobecna „,nową klasą”, jak ją często nazywano. Jest to dość ironiczne, gdyż przez większość czasu zachowywaliśmy się jak zupełnie przeciętni naukowcy, którzy zajmowali się grzebaniem w pismach Marksa i Engelsa (i ich kontynuatorów) w poszukiwaniu materiału pomocnego w zrozumieniu granic i szans współczesnego kapitalizmu.

Prześwietlaliśmy Kapitat i inne sztandarowe teksty pod kątem uwarunkowań autodestrukcji kapitalizmu. Czy źródłem pogłębiającego się kryzysu była nadprodukcja, czy też malejąca stopa zysku? Jak niebezpieczny był międzynarodowy system kapitalistyczny? Jak państwo kapitalistyczne a może państwo w społeczeństwie kapitalistycznym - panowało nad tymi kryzysami i jednocześnie regulowało walkę klas? Jakie były relacje państwa i klasy panującej? Czy klasa panująca w ogóle kiedykolwiek rządziła? Czym w ogóle są klasy? Czy są obserwowalne? Jak rozpoznać czyjąś 
klasowość? I bardziej konkretnie, jak wyjść poza marksowską dwubiegunową koncepcję struktury klasowej? Co jest średniego w klasie średniej? Przechodząc do nadbudowy: Jak klasy się reprodukują? Kto produkuje idee wiodące - ideologię - i jak to się dzieje, że są one przyjmowane przez rządzonych? Jaka jest rola edukacji - czy jest narzędziem mobliności, czy panowania klasowego? Co z płcią? Czy marksiści mogliby zaadaptować patriarchat do dziedziny analiz klasowych? Czy małżeństwo marksizmu z feminizmem było od początku skazane na niepowodzenie? A co z rasa? Czy podział rasowy był jedynie sposobem podziału klasy pracującej, czy raczej metoda reprodukcji taniej siły roboczej? Jaka była szansa na koalicję klasową ludności białej i czarnej? To tylko niektóre z zagadnień, pojawiających się w zbiorze Levine (2004), wyrażających namiętność, z jaką poszukiwaliśmy nowego świata.

Nie ma wątpliwości, że pisaliśmy przede wszystkim dla siebie aspirowaliśmy do tego, by stworzyć, jak ujął to Dick Flack (1972), „socjalistyczna socjologię”. Przypuściliśmy atak na dwa fronty w celu zastapienia socjologii marksizmem - stanowczo krytykując tę pierwszą i wprowadzając twórczą reinterpretację tego ostatniego. Nasze wysiłki skierowane były głównie ku ,teoretycznej praktyce”, wprowadzonej przez Louisa Althussera - ku próbie wyzwolenia marksizmu ze stalinowskiego brzemienia w postaci francuskiej Partii Komunistycznej. Jednakże, czy nie było dziwne, że marksiści uważali idee za tak ważne? Czy nie było niepokojące, że włożyliśmy tak mało wysiłku w przekonanie ludzi niezwiązanych z uniwersytetem o wadze i sile naszych idei?! Co zamierzaliśmy?

Wbrew pozorom, nasze działania nie były tak absurdalne, jak mogłoby się zdawać. Zarysowanie kontekstu uchyli rąbka tajemnicy. Świat stał wówczas w płomieniach - ruchy studenckie przypuszczały gwałtowne i często brutalne ataki na cytadele władzy, od Meksyku po Pekin (pamiętajmy o Kulturalnej rewoluciji na Uniwersytecie w Pekinie Victora Nee), od Berlina po Tokio, od Manili po Seul, od Berkeley aż do Paryża. Była to era protestów w obronie praw obywatelskich w całych Stanach Zjednoczonych, a przez wszystkie kraje zaawansowanego kapitalizmu - i nie tylko - przetoczyły się fale demonstracji przeciw wojnie w Wietnamie. Był to też czas wybuchu Praskiej Wiosny, a także rewolucji w krajach Trzeciego Świata spod znaku Regisa Debraya, Franza Fanona i Che Guevary. Był także ruch kobiecy, atakujący tak wiele instytucji. Amerykańskie Towarzystwo Socjologiczne nie uciekło z pola bitwy: walczący Afroamerykanie, Latynosi, kobiety, socjologowie wyzwolenia wszyscy oni domagali się reprezentacji w swoim stowarzyszeniu. Rodził się nowy porządek, który musiał początkowo zmierzyć się z silnym oporem ze strony mainstreamowej socjologii. Radykalni socjologowie lat 70 . 
usiłowali wpisać $\mathrm{w}$ teorię to, co działo się w praktyce, próbując nadążyć za światem brzemiennym w swoje przeciwieństwo. My zaś jedynie kontynuowaliśmy rewolucję na uniwersytetach - bastionach władzy w społeczeństwie wiedzy.

Los socjologii mimo wszysto spoczywał nadal w rękach mesjanistycznej profesury, która, podczas gdy getta stały w płomieniach, a na ziemię spadały bomby $z$ napalmem, sławiła nieśmiertelne cnoty „Ameryki” - jej liberalną demokrację, otwartość, dynamikę gospodarki, dobrobyt, wysławiając ja jako „pierwszy nowy naród”. Wykształceni w duchu strukturalnego funkcjonalizmu ci socjologowie-misjonarze widzieli siebie jako obrońców konsensusu, wynalazców teorii stratyfikacji, demistyfikujących działania zbiorowe jako w pełni irracjonalne, gorących zwolenników tez o wspólistnieniu ras i komplementarności ról płciowych, no i, oczywiście, apostołów końca ideologii. Socjologia, pogrzebana przez Alvina Gouldnera (1970) - socjologa krytycznego par excellence - popadła w głęboki kryzys z powodu swoich założeń oraz dominujących teorii, które nie dotrzymywały kroku społeczeństwu, choć miały służyć jego zrozumieniu.

Ów radykalny atak na powojenną socjologię okazał się zaskakująco skuteczny. Począwszy od wczesnych lat 70., kolejne jej bastiony padały pod naporem najeżdżających sił: teoria stratyfikacji ustąpiła miejca analizie klasowej, a potem szerszym badaniom nierówności, analizę warunków istnienia liberalnej demokracji porzucono na rzecz badania państwa i rewolucji, społeczno-psychologiczna adaptacja do warunków pracy umożliwiła rozwój teorii alienacji i transformacji pracy, role płciowe wyparła koncepcja dominacji płciowej, konsensus co do wartości zastapiony został idea dyfuzji ideologii panujących za pośrednictwem szkoły i mediów, teoria irracjonalnych zachowań zbiorowych przerodziła się w politykę ruchów społecznych. Twierdza ostatecznie upadła: starzy klasycy odeszli, a w ich miejsce pojawili się nowi. Marks i Engels stali się częścią kanonu, a Durkheim i Weber zostali poddani radykalnym reinterpretacjom. Niedługo potem do drzwi zapukał feminizm i Foucault.

Kolejne klęski wydawały się przekraczać możliwości naszej dyscypliny, lecz socjologia $\mathrm{w}$ istocie reorganizowała się od środka, aczkolwiek z nasza pomoca. W wyniku ledwie uświadomionej wojny pozycyjnej socjologia wymyśliła swój kształt na nowo poprzez selektywne przywłaszczenie sobie socjologii radykalnej. Rezultat był zatem daleki od naszego wyobrażonego projektu socjologii socjalistycznej. W rzeczy samej, pojęcie socjalizmu zostało wymazane $\mathrm{z}$ socjologicznego słownika nawet przed upadkiem muru berlińskiego. Z pewnością główny nurt socjologii wchłoną zbyt duża, niemal śmiertelną dawkę marksizmu i feminizmu. Jednakże nie zginął od niej, a jedynie poddusił się i wypluł sporo spośród krytycznych 
składników. Zostaliśmy ostrzeżeni. Od samego początku krytyczni teoretycy, będący pod wpływem frankfurtczyków, pozostawali sceptyczni co do konkurowania z nauką burżuazyjną na jej własnym boisku ze względu na zagrożenie utrata zmysłu krytycznego i stępienia zdolności do myślenia o tym, co mogłoby być w miejscu tego, co jest teraz. Nauka stanowiła problem, a nie rozwiązanie. Omijając niewygodna debatę o celach i wartościach, nowy marksizm mógł skończyć, reprodukując stosunki dominacji, które miał zwalczać. Foucault zaś wbijał ostatni gwóźdź do trumny nauki, dając wyraz swojemu przekonaniu o żelaznym uścisku wiedzy i władzy. To zaś wprowadziło socjologię radykalną w ślepy zaułek - jakże daleko od jej podmiotów historii - zepchnęło w defensywę. Socjologia radykalna została wchłonięta przez praktyki socjologii jako takiej.

Postulaty teoretyków krytycznych i poststrukturalistów nie były do końca chybione, ale utracili oni to, co już zostało zdobyte. Nawet jeśli marksizm i feminizm udowodniły, że nie ciagną socjologii na dno, lecz wręcz przeciwnie - dążą ku jej ocaleniu, to jednak nowa dyscyplina wyparła starych strażników funkcjonalizmu strukturalnego razem z jej namaszczonymi następcami. Ci z kolei potwierdzili swój kres, manifestując swoje niezadowolenie z powodu kondycji dyscypliny. W latach 80. i 90. słyszeliśmy wiele o rozpadzie socjologii, o jej niespójności, fragmentacji i wreszcie o tym, że brak jej rdzenia, wokół którego by się skupiała. W takich książkach, jak na przykład Socjologia amerykańska w poszukiwanin to:ssamości (tytuł oryg.: The Impossible Science) Stephena Turnera i Jonathana Turnera (1990) [wyd. polskie 1993 - przyp. K.M.], The Decomposition of Sociology Irvinga Louisa Horovitza (1993) czy w What's Wrong with Sociology? (1993), w której Stephen Cole zawarł głównie lamenty starej gwardii nad tym, w jak złej kondycji jest nasza dziedzina. W ostatniej z wymienionych książek Seymour Martin Lipset narzekał na upolitycznienie - w przeciwieństwie do nowego pokolenia jako młody człowiek był uczony, by koniecznie oddzielać politykę i naukę. James Coleman napisał wiele (1990-1991) o inwazji „norm” (które wszak zawsze stanowią potencjalne zagrożenie w świecie teorii racjonalego wyboru), zakłócających swobodny przepływ idei na uniwersytecie. Turnerowie spisali zaś na nowo historię socjologii (1990) - teraz wszak nauki niemożliwej (impossible science). Od samego początku była za słaba, by stanąc na własnych nogach, pozbawiona zasobów i sponsorów, zaszczuta przez kontrowersje opinii publicznej. Jakaż zmiana tonu po triumfalizmie lat 50., kiedy Merton, Lazarsfeld, Stouffer, Parsons i Shils widzieli w socjologii naukę nowej ery!

Teraz natomiast, gdy pokolenie starych mistrzów zostało wyrzucone poza nawias, socjologia straciła swój program, stanowiący amalgamat wielkiej teorii i roztargnionego empirycyzmu, z „teorią średniego 
zasięgu", rozpiętą między tymi dwiema skrajnościami, budowany pod nadzorem sieci oldboyów, sięgającej zaledwie kilku elitarnych wydziałów. Od tamtej pory Amerykańskie Towarzystwo Socjologiczne przeszło proces demokratycznej decentralizacji, zdemonopolizowano czasopisma socjologiczne, sekcje, nagrody. Dla tych, którzy stracili kontrolę, oznaczało to nastanie anarchii, przerywającej wzajemne porozumienie konieczne dla rozwoju nauki i dlatego znamionujące nadchodząca zapaść socjologii. Ci spośród starej gwardii, którzy mieli zacięcie polityczne, szukali możliwości cofnięcia czasu. W latach 80. i 90. próbowali doprowadzić do ponownej centralizacji, zapewnić sobie kontrolę nad pismami naukowymi lub założyć nowe, wspierać zwierzchnictwo instytucji elitarnych, zniszczyć reprezentację demokratyczną w Amerykańskim Towarzystwie Socjologicznym, uciąc kariery niewiernych i narzucić nowe hegemoniczne projekty, oparte na metodach ilościowych lub teorii racjonalnego wyboru. Wszystko to z małym pożytkiem. Stara gwardia nie mogła przeżyć swojej porażki. Pokolenie ich sukcesorów, wychowane na socjologii krytycznej, przejęło kontrolę nad procesem decentralizacji, otworzyło drzwi dla grup mniejszościowych, pogłębiło partycypację i zabrało się za tworzenie alternatywnych socjologii.

Jeśli impulsem stojącym za „radykalną socjologia” lat 70. była chęć dotrzymania kroku burzliwie zmieniającemu się światu, wieszczącemu rewolucyjną zmianę, to dziś zmierza on w przeciwnym kierunku. Świat bowiem jest daleko w tyle za socjologia. Teraz nie chodzi już o reformę socjologii, lecz o zmienienie świata. Przywołując określenia Karla Mannheima (1936), możemy powiedzieć, że w przeciagu ostatnich pięćdziesięciu lat socjologia zmieniła się $\mathrm{z}$,ideologii” afirmującej status quo na coś pokrewnego „utopii”, zagrażającej „granicom istniejącego porządku”. Nie chodzi tylko o to, że socjologia stała się bardziej „radykalna” - świat stał się także bardziej reakcyjny (a zarazem bardziej podstępny i zdradziecki w naturalizacji przerażających wyczynów). Mówiąc wprost, tyrania rynku i despotyzm państwa spowodowały pogłębienie nierówności i zniesienie wolności zarówno wewnątrz, jak i między narodami - obie te tendencje rozpętały się po upadku komunizmu i skonsolidowały w wyniku ataków z 11 września 2001 r. Jeżeli są jakieś punkty oporu wobec naporu tych sił, to należy ich szukać w społeczeństwie obywatelskim, wylęgarni ruchów broniących praw człowieka, sprawiedliwości ekologicznej, uczciwych warunków pracy itp. To jest właściwy grunt socjologii. W tych walkach ma ona do odegrania ważną rolę, zarówno w kwestii podtrzymywania społeczeństwa obywatelskiego, jak i w szkoleniu organizacji i ruchów związanych ze swoją dziedzina. 
Czemu socjologia miałaby wziąc na siebie takie brzemię? Jeśli politologia może być wydzielona ze względu na jej przedmiot i przesłankę, to jest państwo i obronę porządku, jeśli ekonomia może także być wydzielona ze względu na te kryteria, którymi w jej przypadku są rynek i jego ekspansja, to przedmiotem i wartością stojąca za socjologia sa społeczeństwo obywatelskie i jego żywotność. Z pewnością są to jedynie ogólnikowe twierdzenia, które nie pozwalaja zgłębić różnorodności tych dyscyplin i powoduja zignorowanie na przykład pierestrojki w przypadku politologii i pojawienia się prominentnych dysydentów w obrębie ekonomii - Josepha Stieglitza, Amatya Sena i Paula Krugmana, by wymienić tylko kilku. W rzeczy samej, żadna dziedzina nie jest jednorodna, choć każda z nich ma swój rdzeń, swoja główną tendencję, która ustala linię opozycji. Tak więc socjologia także nie stanowi monolitycznej awangardy, podsycającej płomień społeczeństwa obywatelskiego. Ona także ma swoje frakcje opozycyjne, tak konserwatywne, jak i radykalne, które czerpia zarówno z ekonomii czy politologii, jak i - choć w mniejszym stopniu $z$ antropologii, nauk humanistycznych, czy nawet biologii. Dyscypliny naukowe nie są wodoszczelne. Tak jak socjologia czerpała od swoich sąsiedzkich dyscyplin, tak twórcy politologicznej pierestrojki i dysydenci ekonomii czerpia z zasobów socjologii. Lecz - znowu - te przeszczepy odbywają się przy zachowaniu generalnych ram poszczególnych dyscyplin. Zatem państwa i rynki stanowią pola zainteresowania socjologów, ale tylko o tyle, o ile maja związek ze społeczeństwem obywatelskim lub są zanurzone w tkance społecznej.

Niechaj wyrażę się jasno - projekt kształtu naszej dyscypliny nie może i nie powinien ograniczać się do s o c jologi k kry tyc z nej, która nie ma sensu wobec braku socjologii akademickiej (proffesional sociology), którą można by krytykować, lub nawet socjologii, która można by natchnąc jej zobowiązaniami, a wszystkie trzy znajdują swoje dopełnienie w policy sociology, która cechuje się bardziej instrumentalnym rozkładem wiedzy. Celem tego artykułu nie jest szczegółowe wyłożenie koncepcji podziału naszej dyscypliny na te cztery składowe. Niechaj czytelnikowi wystarczy stwierdzenie, że dobra kondycja socjologii zależy od współzależności i wzajemnych powiązań pomiędzy tymi czterema socjologiami, nawet gdy uznamy, że nie są one równie istotne (patrz: Burawoy i in. 2004). Profesjonalna socjologia, czyli taka, w obrębie której rozwijane są programy badawcze, działa głównie w polu akademickim. To ona w szczególności dostarcza pozostałym trzem komponentom legitymizacji i wiedzy eksperckiej. Z drugiej strony, to ona definiuje cały projekt socjologii jako taki, który nierozerwalnie związany jest ze społeczeństwem obywatelskim. 
Związek socjologii ze społeczeństwem obywatelskim jest dla naszej dziedziny tak samo niezbędny, jak unia ekonomii i gospodarki, a oba te powiązania są wypadkowymi historii ${ }^{3}$. Socjologia wzrastała w XIX w. wraz z narodzinami społeczeństwa obywatelskiego - którego historia w Stanach Zjednoczonych rozpoczęła się od narodzin ruchów reformatorskich, naprawczych, wspólnot religijnych, by osiagnąć pełnoletniość w Europie u schyłku wieku razem z rozwojem powszechnego szkolnictwa, partii politycznych, związków zawodowych, organów opinii publicznej i całej gamy stowarzyszeń. Tam, gdzie umarło społeczeństwo obywatelskie, jak na przykład w Związku Radzieckim za czasów Stalina, w faszystowskich Włoszech czy też w Chile pod wodzą Pinocheta, zanikła także socjologia. Tam, gdzie się odrodziło - w brzasku pieriestrojki w ZSRR, z rozkwiem wspólnot pracowniczych w Południowej Afryce i stowarzyszeń walczących o prawa obywatelskie w Stanach - tam socjologia również się wskrzeszała. Los współczesnej socjologii jest zatem zależny od jej spokrewnienia z dynamicznym społeczeństwem obywatelskim i z tego powodu jej interes pokrywa się z uniwersalnym interesem ludzkości, jakim jest powstrzymanie terroru państwowego i utowarowienia wszystkich dóbr, tzn. neoliberalizmu, jak zwykliśmy nazywać mieszankę tych dwu śmiercionośnych składników.

\section{/// XXI wiek: perspektywy dla socjologii obywatelskiej}

Moja teza zatem brzmi następująco: socjologowie krytyczni winni nie skupiać się aż tak bardzo na radykalizowaniu socjologii profesjonalnej, gdyż na to zaw z ze będzie czas, lecz raczej wspierać socjologie obywatelskie, by te z kolei dopingowały rozrost społeczeństwa obywatelskiego. To tyle, jeśli chodzi o decydujące zadanie dla socjologii obywatelskiej, lecz co z jej perspektywami na przyszłość? Istnieje sporo dowodów na to, że taki otwarty projekt ma wsparcie dzięki nastrojom narastającym wśród amerykańskich socjologów ${ }^{4}$.

Spektrum ich inicjatyw odpowiada wachlarzowi politycznych opcji. Możemy zacząć od wariantu najmniej radykalnego, w który wpisuje się nowe pismo „Contexts”, rozpowszechniające wyniki najlepszych i najistotniejszych dla opinii publicznej badań społecznych. Mimo że ów periodyk nie znalazł jeszcze szerokiego grona czytelników, został entuzjastycznie przyjęty przez socjologów. Innym wskaźnikiem zewnętrznej aktywności jest działalność kierownictwa ASA, które pod naciskiem członków towarzystwa

\footnotetext{
${ }^{3}$ Jak pokazała Marion Foucarde-Gourinchas (2003), relacja ekonomii i gospodarki jest dużo bardziej samoświadoma i przejrzysta, co oczywiście jest po części przyczyną jej - ekonomii - sukcesu.

${ }^{4}$ Oczywiście, w wielu krajach Trzeciego Świata socjologia jest socjologią obywatelską. Tylko w Stanach Zjednoczonych, gdzie profesjonalna socjologia jest tak silna trzeba było ukuć pojęcie socjologii obywatelskiej. W niniejszym eseju zajmuję się głównie Stanami Zjednoczonymi, lecz patrz także: Burawoy (2003a).
} 
prowadziło kampanię na rzecz obrony prawa do prowadzenia eksperymentów na ludziach w takich dziedzinach, jak życie seksualne, co zostało uprzednio podważone przez Kongres i Ministerstwo Zdrowia. Dalej, kierownictwo ASA broniło socjologów, uwięzionych za działalność w obronie praw człowieka, na przykład Egipcjanina Saada Ibrahima. Oprócz tego udzielało wsparcia tym wydziałom socjologii, tak w kraju, jak i za granica, którym groziło zamknięcie.

Jednakże w 2003 roku Amerykańskie Towarzystwo Sojologiczne występowało w sprawach przekraczajacych jego korporacyjny interes. Przedłożyło, jako przyjaciel sądu, list do Sądu Najwyższego w obronie akcji afirmatywnej w Michigan Law School, a także wyraziło swój sprzeciw wobec kalifornijskiej Racial Privacy Initiative ${ }^{5}$. Co bardziej kontrowersyjne, a zarazem stanowcze, większością dwóch trzecich poparła zainicjowaną przez członków ASA uchwałę przeciwko wojnie w Iraku. Członkowie głosowali w pełni świadomi jej niekorzystnych skutów dla naszej dyscypliny. W 1968 roku, u szczytu protestów przeciw wojnie w Wietnamie, analogiczna uchwała została odrzucona przez większość dwóch trzecich. Podczas gdy w sondażu nieco ponad połowa (54\%) badanych sprzeciwiała się wojnie w Wietnamie, trzydzieści pięć lat później aż trzy czwarte respondentów było przeciwnych wojnie w Iraku. Wszystko to świadczy o tym, że socjologowie stali się bardziej krytyczni w stosunku do państwa i lepiej przygotowani, by dać wyraz swojemu niezadowoleniu ${ }^{6}$.

Nie tylko zbiorowe sentymenty predysponuja socjologię do decyzji o wejściu do debaty publicznej - także zdecentralizowana struktura dyscypliny stała się lepiej przystosowana do docierania do wielu różnych publiczności. Jeśli decentralizacja sekcji, pism naukowych, hierarchii prestiżu itd. zdaniem niektórych zwiastowała upadek socjologii, to dla innych oznaczała postęp i ocalenie dialogu publicznego. Podział na częściowo

\footnotetext{
${ }^{5}$ The Racial Privacy Initiative: projekt poprawki do Konstytucji Kalifornijskiej, odrzucony w referendum w październiku 2003. Twórcy Racial Privacy Initiative domagali się zakazu klasyfikowania studentów, pracowników i wykonawców zleceń według kryterium rasy, etniczności, koloru skóry. Według inicjatorów miał to być pierwszy krok w kierunku społeczeństwa „ślepego na kolor” (colorblind society) [przyp. tłum.].

${ }^{6}$ Oczywiście nie obyło się bez sprzeciwów. Sześćdziesięciu dziewięciu socjologów podpisało się pod petycją skierowaną do komisji etycznej ASA, w której napisano, że rezolucja wyrażająca sprzeciw wobec wojny w Iraku stanowi pogwałcenie kodeksu postępowania Towarzystwa. Panowała atmosfera niepokoju związana z obawą że ASA może przerodzić się w polityczną grupę nacisku i porzucić swoją rolę jako ciała zaangażowanego w dążenie do rozwoju nauki. Komisja etyczna odrzuciła petycję jako niemieszczącą się w zakresie jej kompetencji i na tym sprawa się skończyła. Demokratyczna struktura ASA znów dała o sobie znać, gdy zażądano, by władze ASA podpisały jakiekolwiek postanowienie członków, jeśli tylko zostanie poparte przez 3\% działaczy, zaś gdyby kierownictwo ASA nie zgodziło się na taką propozycję, domagano się poddania tego pod głosowanie wszystkim członkom ASA. Dla porównania, Amerykańskie Towarzystwo Politologiczne (APSA) i Amerykańskie Towarzystwo Ekonomiczne (AEA) mają konstytucyjny zakaz wydawania uchwał, których treść wykracza poza ich zawodowe interesy.
} 
pokrywające się, lecz spójne subdyscypliny - płeć i gender, socjologia medycyny, pracy, związków zawodowych, rasy i etniczności, przestępczości i dewiacji, imigracji itd. - określa zasięg aktualnej debaty publicznej i tematów, ku którym socjologowie powinni kierować swoją uwagę. Ważne, żeby tym różnorodnym polom nadać pewną podstawową spójność i z tego powodu także większe działy - jak kulura, polityka, socjologia, teoria mają do odegrania swoją ważną rolę. Te filary nadają naszej dyscyplinie najszersze znaczenie, stanowią wizje, które są kultywowane, wspierane, przekierowywane i rekonstruowane przez socjologię krytyczna - refleksywny rdzeń naszej dyscypliny lub jej zbiorową świadomość, jeśli ktoś woli takie określenie.

Likwidatorzy socjologii - hegemoni zeszłej ery - życzyliby sobie innej dyscypliny, tzn. takiej, która byłaby zbliżona do ekonomii, gdzie obserwowane obiekty i zbiór założeń nie tworzą rozproszonej świadomości zbiorowej, lecz spójny zestaw przesłanek, modeli, przykładów. Jedność jest ceną którą wszyscy muszą ponieść. Ekonomia zorganizowana jest niczym partia komunistyczna: ma swoiste politbiuro, które steruje dyscyplina w kraju i rozpowszechnia doktrynę rynkowa za granica - wszystko to pod hasłem wolności wyboru. Taki scentralizowany despotyzm prowadzi do efektywnych interwencji na arenie politycznej, gdzie ceni się stanowcze twierdzenia. Jest to wizja bardzo daleka od szerokiego wachlarza częściowo pokrywających się subdyscyplin socjologii, której zdecentralizowany świat sprzyja wielogłosowym dyskusjom wśród różnych publiczności. Jesteśmy mniej efektywni jako służba władzy, ale lepiej sprawdzamy się mobilizując, edukując, zwiększając świadomość, zmieniając prywatne problemy w sprawy publiczne. Heterogeniczność naszej dyscypliny sprawia, że lepiej nadajemy się do roli w debacie publicznej niż w służbie polityce.

Oczywiście może się okazać, że to nie struktura naszej dyscypliny upośledza nas w polu politycznym, lecz także przesłanie, jakie chcemy przekazać. Władze Stanów Zjednoczonych są coraz mniej zainteresowane zapewnieniem praw społecznych i ekonomicznych - zagwarantowaniem minimum socjalnego, ochroną wolności cywilnej, zwalczaniem rasizmu, ulepszaniem publicznej służby zdrowia dla wszystkich obywateli, tworzeniem coraz bezpieczniejszego świata dla każdego. Być może na szczeblu lokalnym, gdzie władze miejskie są bardziej wyczulone na potrzeby obywateli, jest więcej możliwości dla interwencji socjologicznych. W rzeczy samej, jako że państwo narodowe coraz mniej troszczy się o swoja misję publiczna, staje się coraz mniej społecznie odpowiedzialne, a bardziej dba o swój prywatny interes, coraz więcej zadań, takich jak zapewnienie edukacji, godnych warunków życia, opieki zdrowotnej i bezpieczeństwa spada na barki władz lokalnych. To jest teren bardziej 
sprzyjający obywatelskiej socjologii ${ }^{7}$. Odkładając kwestię policy sociology (socjologii stosowanej) na bok musimy się jednakże zastanowić, czy nasze przesłanie nie jest za bardzo na lewo od przekonań opinii publicznej w Stanach? Czy możemy wywołać iskrę, który rozpocznie dyskusję?

Błędem byłoby niedocenienie luki, lecz równie nierozsądne byłoby zignorowanie dotychczasowych sukcesów. Dla przykładu, zaobserwowałem wielkie podekscytowanie związane z założeniem nowej sekcji ASA, która ma zajmować się nowa pracą i ruchami pracowniczymi a także założeniem Instytutu Pracy i Zatrudnienia na Uniwersytecie w Californii, który w swej krótkiej historii wsławił się wsparciem niecodziennej współpracy między światem pracy a socjologia, polegającej na przykład na obserwacji podrzędnych warunków pracy, strategii organizacji kampanii i zmieniającego się wizerunku rynku pracy, urlopów macierzyńskich, nie mówiąc o roli edukacyjnej centrów pracy ${ }^{8}$. Ich żywotność i sukces kontrastowały z chłodną obserwacją ze strony prawicowych think-tanków i prasy konserwatywnej. Mimo poważnej batalii ta inicjatywa stała się jedną z pierwszych ofiar reżimu Schwarzeneggera. Obserwując inne obszary działania socjologów, należy powiedzieć o ich zaangażowaniu $\mathrm{w}$ dialog ze wspólnotami religijnymi, społecznościami więźniów, wspólnotami sąsiedzkimi i grupami imigrantów. Trzeba zatem uważać, by nie zredukować socjologii obywatelskiej do jej „tradycyjnej” formy - działu opinii w państwowych gazetach. Mimo że te interwencje na szczeblu narodowym są istotne, to zasłaniają one bogata paletę socjologii obywatelskich tworzonych oddolnie lub „organicznie”, mniej zauważalnych, lecz nie mniej ważnych. Musimy odnaleźć to, co dotychczas było traktowane jako marginalne i przynależne do sfery prywatnej, aby uprawomocnić socjologię obywatelską - we wszystkich jej odcieniach - poprzez postawienie jej w roli towarzysza socjologii profesjonalnej. Z pewnością truizmem jest twierdzenie, że studenci są nasza pierwsza publicznością i że to oni przenoszą dyskusję na tematy socjologiczne do innych grup, które możemy nazwać publicznością wtórną. Możemy jednakże pomyśleć o socjologii obywatelskiej jako o rozwinięciu naszej roli jako nauczycieli - jako o dostarczaniu wiedzy socjologicznej do wielu różnych odbiorców. Tak samo bowiem jak w przypadku studentów, którzy

\footnotetext{
${ }^{7}$ Możliwości dla rozwoju socjologii obywatelskiej różnią się w zależności od stanu. W czasach Nowego Ładu i Ery Praw Obywatelskich socjologia głębiej wnikała w struktury agencji federalnych niż w czasach państwa neoliberalnego. W tym samym czasie obserwujemy, że w takich państwach jak Norwegia, Finlandia czy Szwecja socjologia cieszy się dużo silniejszą pozycją na szczeblu rządowym. Jednakże w dalszym ciagu obstawałbym przy tym, że stosunkowa przewaga socjologii i jej spontaniczny sprzeciw ma swoje źródła w społeczeństwie obywatelskim i autonomia policy sociology (socjologii stosowanej) będzie zależała od siły socjologii obywatelskiej.

${ }^{8} \mathrm{~W}$ ten sposób Edna Bonacich, autorka artykułów na temat rozpadu rynku pracy, podążała za tropem socjologii obywatelskiej, badając przemysł odzieżowy, ściśle współpracując z Unią (UNITE) i kampanią przeciw zakładom zatrudniającym niskopłatnych pracowników (Bonacich i Appelbaum 2000).
} 
początkowo mogą nie przyjmować naszej wiedzy, by po jakimś czasie stać się jej gorącymi zwolennikami, może stać się z naszymi odbiorcami z kręgów poza uniwersytetem.

Nie skończyliśmy jeszcze rozprawy $\mathrm{z}$ siewcami ponurych wizji dotyczących przyszłości socjologii. Politolodzy, tacy jak Robert Putnam (2000) czy Theda Skockpol (2003), zachęcani i wspomagani przez socjologów, biją na alarm w sprawie społeczeństwa obywatelskiego, wchłanianego przez państwo, biurokrację i media. Rezultaty ich badań nie są jednoznaczne, lecz - pomijając ten wątek - jeśli zasoby kapitału społecznego rzeczywiście maleja, to właśnie naszym zadaniem jest powstrzymanie tego procesu. Powinniśmy w tym miejscu pomyśleć o ruchach feministycznych, w które zaangażowanych było także wielu socjologów, a których wielkim sukcesem była zmiana pozycji społecznej kobiet, przekształcenie ich $\mathrm{z}$ biernych $\mathrm{w}$ podmioty aktywne na arenie publicznej gotowe do walki o swoje interesy. Jako socjologowie nie tylko tworzymy nowe kategorie, ale także nadajemy im wartość zarówno normatywną, jak i polityczna. Jeśli tu ponosimy porażkę, to dajemy wolną rękę państwu i rynkowi, które ową nieopisana przez nas pustkę znaczeniową wypełniaja w sposób odpowiadający ich własnym potrzebom. Wspieramy takie grupy docelowe, jak ubodzy, przestępcy, więźniowie, kobiety z rakiem piersi, osoby chore na AIDS, samotne kobiety, homoseksualiści itd. nie po to, by je kontrolować, lecz po to, by zwiększyć ich potencjał do samookreślenia. Nie powinniśmy powierzać ich losu państwu, lecz angażować ich bezpośrednio. Kiedy badamy ruchy społeczne, zarazem potwierdzamy ich obecność w sferze publicznej. Powinniśmy być bardziej samoświadomi w kwestii naszych relacji z ludźmi, których badamy i skutków, jakie wywołuja nasze badania.

Jeśli w dalszym ciagu pozostaje trochę sceptyków wobec postulatów socjologii obywatelskiej - takich, którzy uważaja, że gleba, na której wzrasta społeczeństwo obywatelskie, jest zbyt jałowa - zawsze możemy uciec się do poparcia wśród członków naszych własnych organizacji. Jedną ze specyficznych cech amerykańskiego społeczeństwa obywatelskiego jest obecność silnych i niezależnych organizacji, skupiających przedstawicieli określonych zawodów. Z pewnością zazwyczaj zabezpieczają one swoje własne zbiorowe interesy, ale nie w każdym przypadku. Na przykład jeśli chodzi o obywatelskie zaangażowanie profesji, prym wioda tu prawnicy, troszczący się o ochronę praw człowieka i praw obywatelskich. Te zabiegi moga nie przekraczać działań koniecznych do stworzenia przyjaznego wizerunku, maskującego wielką potęgę tych organizacji, lecz mimo wszystko jest to niezmiernie istotne zjawisko. Socjologia jako dysycplina naukowa narodziła się jako bliska krewna reform moralnych, tak jak 
indywidualni socjologowie „rodzą się” do tego zawodu w efekcie moralnej walki. Profesjonalizm próbował zdusić instynkt moralny w obrębie nauki, tak jak i nas zmusił do karier, w których każe się nam zdystansować wobec zobowiązań moralnych. Problem moralności jednakże, nawet jeśli jest marginalizowany i represjonowany, może zostać zawieszony albo odroczony, ale nigdy nie znika. Wraca on niczym bumerang w najmniej oczekiwanym momencie. Jak zaobserwowaliśmy, pozytywne nastawienie względem obywatelskiego zaangażowania swojej profesji wśród socjologów przybiera na sile. Jest pewną - korzystną w tym przypadku - ironią, że kiedy społeczeństwo było silne, socjologia krytyczna zwracała się do wewnątrz, zaś teraz, gdy społeczeństwo osłabło, socjologia krytyczna zwraca się na zewnątrz.

Próbując obalić argumenty sceptyków nie chcę jednakże zabrzmieć jak ktoś zbyt pewny swego zwycięstwa. Nie wolno nam bowiem zapomnieć, że jesteśmy jedynie socjologami krytycznymi, których szkolono, by widzieć nie tylko to, co złe, ale i to, co dobre! Uwypuklając tak szanse, jak i konieczność podnoszonych przez nas kwestii, nie możemy tracić z oczu przeciwwagi socjologii obywatelskiej, jaką stanowi profesjonalna socjologia. Nie chodzi tu tylko o jedno, raczej obojętne, pokolenie, lecz - jak ujął to Andrew Abbot (1988) - o tendencję wpisaną w istnienie zawodów, która polega na budowaniu ich statusu poprzez dystansowanie się wobec całego społeczeństwa i fetyszyzowanie niedostępności ich wiedzy dla zwykłych obywateli. Zawsze będzie obecne pewne napięcie między socjologią profesjonalną a obywatelska, którym zarządzać musi socjologia krytyczna.

\section{/// Realne utopie: agenda dla krytycznej socjologii obywatelskiej}

„Krytyczny zwrot” ku socjologii obywatelskiej ma dwa różne znaczenia. Dotychczas zajmowaliśmy się tylko jednym $\mathrm{z}$ nich, mianowicie potrzebą i możliwością zaistnienia socjolologii obywatelskiej. Potrzebą i możliwością przejścia od interpretacji do zaangażowania, od teorii do praktyki, od środowiska akademickiego ku społeczeństwu. Jednakże, ko ni e c z ność istnienia socjologii obywatelskiej wynika z ruchu „nożyc” - pole naszej dyscypliny przemieszcza się na lewo, podczas gdy polityka i ekonomia przesuwa się coraz bardziej na prawo.

Istnieje jednakże drugie znaczenie terminu „krytyczny zwrot”, jest to mianowicie zwrot ku krytyce, ku socjologii obywatelskiej, która jest „krytyczna wobec” (critical of), jak i „krytycznie zaangażowana w świat, któremu służy" (critical to), ku socjologii obywatelskiej, która ma na celu raczej przekroczyć niż podtrzymywać to, co istnieje w świecie społecznym. Innymi słowy, socjologia krytyczna nie może popierać każdego zwrotu na zewnątrz, każdego działania rozszerzającego pole społeczeństwa 
obywatelskiego. Nie możemy ufać tendencjom wspólnotowym, w których patrzy się na społeczeństwo obywatelskie i obywateli, którzy są w nie wpleceni, jako szlachetnych przeciwników despotyzmu państwa i tyranii rynku. Społeczeństwo obywatelskie równie dobrze może być narzędziem reżimów autorytarnych i faszystowskich, jak bronić ludzkości przed dyktatura. Jego rozrost i wewnętrzna odporność to warunki konieczne, ale niewystarczające, by skutecznie zwalczać terrorystyczne państwo. Ogólnie rzecz biorąc, społeczeństwo obywatelskie stanowi zaplecze współpracy dla wszystkich państw kapitalistycznych, z którymi łączą je tysiące nitek zależności, odtwarzając zarazem uprawomocnienie kapitalistycznej dominacji. Co więcej, państwa w coraz większym stopniu propaguja społeczeństwo obywatelskie, lecz tylko po to, by przeciążyć je obywatelskimi obowiązkami - cedując na nie odpowiedzialność za publiczny dobrobyt, służbę zdrowia, opiekę nad starszymi, edukację, bezrobocie, biedę, degradację środowiska i tym podobne. W końcu, społeczeństwo obywatelskie samo inicjuje formy dominacji - podziały rasowe, rozproszone systemy hegemonii ról płciowych i seksualności, władzę kapilarna - które nawołują do swoistej wojny pozycyjnej. Nawet jeśli społeczeństwo obywatelskie nie stanowi samo w sobie panaceum, to mimo wszystko pozostaje najlepszym, a właściwie jedynym polem dla socjologów, w którym moga nawigować swoje inicjatywy publiczne.

Przyjmując tezę o Janusowym obliczu społeczeństwa obywatelskiego - które stanowi instrument dominacji, a zarazem pas startowy dla oddolnej inicjatywy - musimy nastawić się na rozwijanie kryteriów normatywnych i instytucjonalnych postępującej interwencji. Musimy wspierać takie społeczeństwo obywatelskie, które jest nie tylko silne i autonomiczne, ale także samorządne, reagujące na rozmaite potrzeby i, ponadto, infiltrujące działania państwa jako takiego. Za społeczeństwo obywatelskie musimy uczynić odpowiedzialnym państwo, które winno rozwijać, promować i chronić zasady demokracji uczestniczącej. To jest wizja, która stała za projektem Wzmocnionego Współrządzenia Partycypacyjnego (EPG: empowered participatory governance) autorstwa Archona Funga i Erika Wrighta (2003) - modelu aktywnego, samorządnego społeczeństwa obywatelskiego, który wyprowadzili z wnikliwych badań nad partycypacyjnym tworzeniem budżetu w Porto Alegre, reformami panczajatu w Kerali, sąsiedzkim zarządzaniem szkołami publicznymi w Chicago i planowaniem ochrony środowiska w Stanach Zjednoczonych. Z obserwacji tych eksperymentalnych metod zarządzania Fung i Wright wywiedli zestaw zasad politycznych, reguł tworzenia i warunków koniecznych dla rozwoju EPG, nad którymi debatowano na wielu konferencjach na całym świecie. 
To przedsięwzięcie wyznacza program dla krytycznego podejścia w socjologii obywatelskiej. Ma ono swój początek w prześwietlaniu wiedzy zdroworozsądkowej różnych wspólnot, którą bada się pod kątem wyłuskania z niej zasad dających się uogólnić, a następnie szkicuje się przystępny projekt, który zarazem stanowi punkt wyjścia do dyskusji w innych społecznościach. Innymi słowy, staje się realna utopia, to jest utopią opartą na istniejącym świecie. Ale analiza nie kończy się w tym miejscu, bowiem zbliża się ona do bogactwa wiedzy socjologicznej, jej naukowego dziedzictwa, by odpowiedzieć na trzy istotne kwestie: jakie są warunki narodzin realnej utopii - czy mogą być przenoszone na grunty innych wspólnot? Jakie są warunki jej istnienia - czy może się ona reprodukować w kolejnych pokoleniach? I wreszcie, jakie są jej wewnętrzne i zewnętrzne niespójności - jaka jest jej długofalowa trajektoria? W tym miejscu znowu odsłaniają się możliwości konwergencji profesjonalnej, obywatelskiej i stosowanej (policy) socjologii na warunkach zdefniowanych przez socjologię krytyczną.

Możemy powiedzieć, że zaangażowanie socjologów krytycznych w budowanie realnych utopii jest integralną częścią projektu socjalizmu socjologicznego. Jest to taka wizja socjalizmu, w której centrum umieszczone jest społeczeństwo ludzkie lub uspołeczniona ludzkość, wizja, która miała kapitalne znaczenie dla Marksa, ale została na długo utracona, zanim podjęli ją Gramsci i Polanyi (Burawoy 2003b). Jeśli socjologia obywatelska ma mieć coraz większy wpływ, będzie musiała zawsze być odpowiedzialna przed pewną wizja demokratycznego socjalizmu.

Przełożyła Karolina Mikołajewska Przekład przejrzał Przemysław Sadura

/// The Critical Turn to Public Sociology, „Critical Sociology” 31/2005: 313-326 (C) Koninklijke Brill NV, Leiden. Published with permission of Koninklijke Brill NV. Dziękujemy za zgodę na opublikowanie przekładu.

Bibliografia:

/// Abbott, A. 1998. The System of Proffesions. Chicago: University Press.

/// Bonacich, E. i Appelbaum, R. 2000. Behind the Label. Los Angeles: University of California Press.

/// Burawoy, M. 2003b. For a Sociological Marxism: The Complementary Convergence of Antonio Gramsci and Karl Polanyi. „Politics and Society” 31: 193-261. 
/// Burawoy, M., Gamson, W., Ryan, C., Pfohl, S., Vaughan, D., Derber, C., Schor, J. 2004. Public Sociologies: A Symposium from Boston College. „Social Problems" 51(1): 103-130.

/// Cole, S. 2001. What's Wrong with Sociology? Nowy Brunszwik: Transaction Publ.

/// Coleman, J. 1990-1991. The Sydney Hook Memorial Award Address: On the Self-Suppresion of Academic Freedom. „Academic Questions” 4(1): 17-22. /// Ehrenreich, B. i Ehrenreich, J. 1977. The Proffesional-Middle Class. „Radical America" 11(2)/1977.

/// Flacks, R. 1972. Toward a Socialist Sociology. „Insurgent Sociologist” 2(2): 18-27.

/// Foucarde-Gourinchas, M. 2003. The Construction of a Global Profession: The Case of Economics. Niepublikowany rękopis, Wydział Socjologii Uniwersytetu Kalifornii w Berkeley.

/// Fung, A. i Wright, E. 2003. Deepening Democracy. Londyn: Verso.

/// Gouldner, A. 1970. The Coming Crisis of Western Sociology. Nowy Jork: Basic Books.

/// Horowitz, I.L. 1993. The Decomposition of Sociology. Nowy Jork: Oxford University Press.

/// Levine, R. (red.) 2004. Eniching the Sociological Imagination: How Radical Sociology Changed the Discipline. Lejda-Boston: Brill Publishers.

/// Lipset, S.M. 2001. The State of American Sociology. W: Cole, S. What's Wrong with Sociology? Nowy Brunszwik: Transaction Publ.

/// MacKinnon, C. 1936. Toward a Femnist Theory of the State. Cambridge. /// Mannheim, K. 1936. Ideology and Utopia: An Introduction to the Sociology of Knowlegde. Nowy Jork: Harcourt Brace Jovanovich (wyd. polskie: 2008. Ideologia $i$ utopia, Warszawa: Aletheia).

/// Nee, V. 1969. Cultural Revolution at Peking University. Nowy Jork: Monthly Review Press.

/// Putnam, R. 2000. Bowling Alone, Nowy Jork: Simon \& Schuster (wyd. polskie: 1996. Bowling alone. Malejacy kapitat spoteczny Ameryki, „ResPublica Nowa" 6).

/// Skockpol, T. 2003. Diminished Democracy. Norman: University of Oklahoma Press.

/// Turner, S. i Turner, J. 1990. The Impossible Science. Newbury Park: Sage Publications. 